\title{
O ZAGADNIENIACH RELATYWIZMU W GLOBALNEJ ARCHITEKTURZE
}

\author{
Aleksander Serafin \\ Wydział Budownictwa Architektury i Inżynierii Środowiska, Instytut \\ Architektury i Urbanistyki, Politechnika Łódzka \\ Faculty of Civil Engineering, Architecture and Enviromental Engineering, Department \\ of Architecture and urban Planning, Łódź University of Technology \\ e-mail: aleksander.serafin@p.lodz.pl
}

\begin{abstract}
Streszczenie. Tekst omawia zagadnienia relatywizmu w kontekście międzynarodowej architektury, jak również konfrontuje je z przeciwnymi tendencjami. Wybrane przykłady świadczą o tym, że tego rodzaju architektura jako wynik globalizmu przeciwstawia się tradycji. Mimo przedstawienia główne aspektów relatywizmu, artykuł ten stanowi również prolegomenę do tendencji absolutystycznych w architekturze. Paradoksalnie absolutyzm nie zawsze narzuca architekturze styl historyzujący, lub monumentalny. Relatywizm jednak nie stanowi jednorodnego stylu i nie posiada sprecyzowanych granic. W tym świetle jakakolwiek próba całkowitej negacji tradycyjnych wartości w procesie projektowania wydaje się być skazana na niepowodzenie.
\end{abstract}

Słowa kluczowe: architektura, relatywizm, absolutyzm, globalizm, ekspresja, forma

\section{WSTĘP}

Architektura poddana procesowi globalizacji konfrontuje ze sobą dwa pojęcia obecne w estetyce, jakimi są relatywizm i absolutyzm. Pierwszy z wymienionych poglądów zakłada, że nie ma porządków niosących za sobą treść absolutną. Ocena dzieła jest bowiem zawsze względna i zależna od kontekstu. Drugie z wymienionych zagadnień charakteryzuje się przyjęciem określonej prawdy estetycznej, niezależnie od tego, czy można dotrzeć do jej źródeł. Koncepcję estetyki w takim antagonistycznym ujęciu prezentował między innymi Tadeusz Pawłowski, który absolutystów przeciwstawia relatywistom, dla których przedmiot nie może samoistnie posiadać wartości estetycznej. Stwierdzenie o istnieniu takiej wartości może stanowić jedynie skrót zastępczy dla wyrażeń zawierających odniesienie do „czynnika relatywizującego", ze względu na który uznaje się ten przedmiot za wartościowy estetycznie [Pawłowski 2010]. Wykraczając poza granice dyskusji o pięknie, relatywizm jawi się jako uniwersalna etyka będąca jedną z konsekwencji unifikacji podążającej za globalizmem [Esikot 2012].

\section{OBIEKTYWIZM: KONTESTACJA KANONU}

Globalna relatywizacja wywołuje zapotrzebowanie na obiektywizm w dziedzinie estetyki. Można przyjąć, że postawa relatywistyczna w ujęciu plastycznym wyraża się poprzez badanie zależności kształtów, barw, faktur, natomiast w szerszym ujęciu estetycznym, także dźwięków, zapachów i innych właściwości podlegających percepcji. Celem jest obiektywizowanie tychże zależności. Wprawdzie należy w tym miejscu przywołać pogląd Michała Sobeskiego który twierdził, że ufundowanie estetyki obiektywnej na zasadach czysto formalnych jest niemożliwością [Sobeski 2010]. Oczywistą staje się zatem potrzeba wprowadzenia elementów „,pozawizualnych". Dlatego też artystyczny relatywizm może koncentrować się na wzajemnych relacjach znaków, rozumianych jako skończone formy graficzne, niosące konkretną i powszechnie rozpoznawalną treść. Te wszystkie ujęcia mają jednak pewien wspólny mianownik. Zawsze odnoszą się one do wzajemnej zależności przynajmniej dwóch, choćby elementarnych zjawisk estetycznych. Podejścia te mają wpisaną w swoją naturę istotę zestawiania. Podobnie 
jak relatywizm w wymiarze etycznym zakłada względność postaw i tym samym nie rozstrzyga w kwestii „dobre - złe”, lecz „,inne”, tak samo w wymiarze estetycznym nie przesądza o poszczególnej formie w kategorii „pozytywna - negatywna”. Nie rozstrzyga o formie samej w sobie, gdyż nie uznaje żadnych punktów odniesienia. W kwestii architektury formalny relatywizm sprowadza się przede wszystkim do zanegowania wypracowanego przez wieki kanonu, będącego swoistym odpowiednikiem absolutu.

Reprezentujący stanowisko relatywistyczne André Breton zwracał uwagę na to, że racjonalizm absolutny pozwalał rozpatrywać jedynie zjawiska związane ściśle z doświadczeniem, natomiast $\mathrm{w}$ świetle racjonalizmu nieuchwytne pozostawały cele logiczne [Breton 1976]. Relatywistyczna postawa jest również efektem filozofii pozytywnej Augusta Comte. Ta bowiem, ograniczając się do sfery rzeczywistości dostępnej dla umysłu, uznawała obiektywizm za ostateczną fazę rozwoju ludzkości, a więc etap który zastąpi fazę metafizyczną. Herbert Spencer zakładał z kolei, że zjawiska psychiczne stanowią jedno z ogniw rozwoju przyrody, dlatego też uznał, że dla umysłu nie ma form niezmiennych [Tatarkiewicz 1970]. Wszechobecna zmienność i względność odnajduje swoje uzasadnienie także w rozwoju dwudziestowiecznej nauki, przede wszystkim w postaci geometrii nieeuklidesowej i teorii względności, co skutkuje poszukiwaniami obiektywnych zasad rządzących nowoczesną sztuką [Kotula, Krakowski 1973]. Podobnie w architekturze ruch nowoczesny wykreował racjonalistyczny utylitaryzm.

Zbudowana na globalnym relatywizmie wiara $w$ obiektywizm i możliwość zracjonalizowania wszelkich procesów społecznych i kulturowych, wydaje się z dzisiejszego punktu widzenia złudna. Stefan Müller stwierdził, że współczesna ucieczka architektów w stronę utylitaryzmu, $\mathrm{z}$ ostentacyjnym odcinaniem się od tradycji wynika z dezorientacji w złożonej współczesności, jak i brak punktu odniesienia, a z drugiej strony jest efektem przesycenia historyzmem. Müller pisze także w tym kontekście o widocznej potrzebie kontestacji w świadomości artystycznej, która sprawia że negacja tradycji została uznana za konieczny składnik twórczości, który legitymizuje umiejętności architektoniczne [Müller 2010]. Jeszcze silniej niż modernizm, negacja tradycji zdaje się charakteryzować poststrukturalizm. To właśnie z nim utożsamiana jest eskalacja relatywizmu [Leach, 1997]. Wprawdzie Mark Wigley inicjując dekonstruktywizm będący najpełniejszym wyrazem myśli poststrukturalistycznej w architekturze, deklarował, że nurt ten wykorzystuje słabości tradycji po to aby ją zakłócić, ale nie zniszczyć jej [Wigley 2013].

\section{ARCHITEKTURA RELATYWISTYCZNA}

Podążająca za globalizmem potrzeba unifikacji stoi w opozycji do tradycji, która per se jest jedną $\mathrm{z}$ istot regionalizmu. Kontestacja architektonicznego tradycjonalizmu ma przede wszystkim charakter ekspresyjny. Ekspresja formy architektonicznej polega na podkreśleniu znaczenia siły ciążenia, lub na jej pozornej negacji [Sławińska 1997]. Ostatnie trzy dekady w globalnej architekturze udowodniły, że poststrukturalizm niejako „przelicytował" ruch nowoczesny w zakresie burzenia klasycznego ładu. Ekspresyjne i bezpośrednie zanegowanie kanonu wydaje się szczególnie widoczne w przypadku trzech obiektów. Pierwszym, zarazem najstarszym z nich, jest nadbudowa kamienicy przy wiedeńskiej Falkestrasse autorstwa Coop Himmelb[1]au. Obiekt jest bezpośrednim przeniesieniem ekspresjonistycznej wizji na grunt realnej architektury [Serafin 2013]. Relatywistyczne idee wyraża forma, która odpowiada samorzutnym procesom ostatecznie zmierzającym w ku chaosowi. Obiekt poprzez swoja lokalizację zostaje jednoznacznie skonfrontowany z historyczną tkanką miejską. Forma tej budowli jest uwolniona z ograniczeń ortogonalnej struktury, a jej rozbicie wprowadza w stan zaniepokojenia, ponieważ forma ta wydaje się przynależeć do całej struktury będąc rodzajem narośli [Wąs 2010]. Wolf D. Prix, główny projektant zespołu odpowiadając na pytanie o filozofię twórczości Coop Himmelb[1]au, mówi o architekturze, która przeskakuje granice tradycji architektonicznej [Prix 2005]. Biorąc więc pod uwagę kosmopolityczny charakter architektury 
tej grupy projektowej, deklaracja wydaje się tym bardziej uzasadniona. Sam Prix mówi o podziale na architekturę globalną i lokalną, zaznaczając przy tym, że z artystycznego punktu widzenia nie interesuje go wymiar regionalny [Prix 2005].

Rozbudowa Muzeum Berlińskiego, dawnego budynku „Kollegienhaus”, zrealizowana w połączeniu z nowym skrzydłem budynku może być rozpatrywana jako drugie kluczowe dzieło poststrukturalizmu. Adaptacja historycznego budynku zrealizowana według projektu Daniela Libeskinda polega między innymi na ekspresyjnym zestawieniu jego elewacji z konstrukcją wsporczą dla przezroczystego zadaszenia atrium. Jest to jednak przykład kompozycji określonej za pomocą ekspozycji paradoksów konstrukcyjnych. Architekt zaznacza bowiem, że „od czasu modernizmu budynki projektowane są tak, by pokazywały światu oblicza neutralne, niepodatne na ekspresję" [Libeskind 2008]. Jeszcze bardziej wyraziście architektura tego twórcy ingeruje w tkankę historyczną w przypadku drezdeńskiego gmachu Muzeum Bundeswehry (Ryc. 1). Ekspresja projektu sprowadza się do symbolicznego „przebicia” zwartej, klasycznej kompozycji historycznej za pomocą klinowo ukształtowanej konstrukcji. Regularność masywnego murowanego obiektu zostaje zaburzona poprzez ekspresję stalowej struktury ukształtowanej na wzór kubofuturystycznej kompozycji. Omawiana twórczość zręcznie zakłóca dominację powszechnie przyjętego porządku estetycznego i kwestionując architektoniczny kanon, podważa wartości tradycyjne.

\section{PRÓBY WSKAZANIA ALTERNATYWNEJ KONCEPCJI ESTETYCZNEJ}

Znaczącą próbę przywrócenia architekturze wartości tradycyjnych stanowi twórczość przedstawicieli tak zwanego „nowego klasycyzmu”. Przedstawiciele tego nurtu poszukują ponadczasowego języka architektury w opozycji do ponowoczesnego relatywizmu, w którym uprawnione jest wszystko i każdy może tworzyć wedle własnych zasad [Zaguła 2013]. Klasycyzm jako styl budowania sprawdził się w różnych czasach, ponieważ był adresowany do różnych warstw społecznych i funkcjonował w społeczeństwach o bardzo różnej organizacji wewnętrznej. W świetle powyższego poglądu klasycyzm ma w sobie potencjał rozwiązania problemu nowoczesnego relatywizmu [Zaguła 2013]. Takie podejście, o ile jest zrozumiałe w określonych okolicznościach urbanistycznych, to jako kompleksowe rozwiązanie na skalę globalną wydaje się dyskusyjne, ponieważ potencjalne hamuje rozwój nowych form w architekturze, która z natury rzeczy jest zobligowana do ich generowania. Budzi to więc wątpliwości odnoszące się do możliwości masowego wdrożenia koncepcji absolutystycznych jako takich. Karsten Harries zwraca uwagę także na to, że historycznie absolutyzm cechował ideologiczną dominację [Harries 2000], co we współczesnych społeczeństwach pluralistycznych wydaje się znacznie ograniczać jego zastosowanie.

\section{EKSPRESJA: METAFIZYKA I FENOMEN}

Współcześnie dostrzegalna jest potrzeba wytypowania architektury, która byłaby zdolna symbolicznie podjąć polemikę z relatywizmem i w wyrafinowany sposób świadomie nawiązać do fundamentów cywilizacji zachodniej. Pewne możliwości w tym zakresie można dostrzec w tradycji ekspresjonistycznej. Pomimo, że ekspresjonizm nie jest zjawiskiem zwartym [Willet 1976], to utożsamiane $\mathrm{z}$ nim pojęcia intuicji i duchowości nadają mu w pewnej mierze wymiar absolutystyczny. Z punktu widzenia historii kultury jest to nurt, który w czasach rozkwitu zrywającej z przeszłością awangardy, jako jedyny sięgnął do konwencji północnoeuropejskiego gotyku. Twórcy podążający za myślą Wilhelma Worringera właśnie w średniowieczu dostrzegli źródła nowoczesnej kultury europejskiej. Aby dotrzeć do istoty architektonicznej ekspresji, należałoby przywołać intuicjonizm Henriego Bergsona i antypozytywizm Benedetto Croce. Obydwie szkoły filozoficzne obsadzają w szczególnej roli twórcę, który z założenia jest obdarzony większą intuicją, niż potencjalny odbiorca jego dzieła. 
Absolutystyczne poszukiwania twórcze mogą opierać się też na fenomenie, co wiąże się z zagadnieniami fenomenalizmu i fenomenologii. Przedstawiciele futuryzmu zajmowali w tej materii stanowisko umiarkowane twierdząc, że celem twórcy jest uchwycenie plastycznego stosunku zachodzącego pomiędzy wiedzą przedmiocie, a fenomenem tego przedmiotu [Boccioni 1988]. Postawa bardziej radykalna pozwoli założyć, że udostępnione przez rzeczywistość gotowe układy doznań zmysłowych i emocjonalnych, można wobec przywołanych wcześniej nauk potraktować wręcz jako punkt wyjścia dla dzieła. Nauki Edmunda Husserla, którego z pewnością można nazwać założycielem ruchu fenomenologicznego, nadają natomiast wysoką rangę intencjonalności. Ukonstytuowanie fenomenologicznego pojęcia przestrzeni, poprzez promocję twórczości architektonicznej opartej na wielozmysłowości, kultura współczesnego zachodu zawdzięcza myślicielom takim jak Maurice Merleau-Ponty głoszący, że percepcja architektury jest wielozmysłowa i dokonuje się za pośrednictwem całego ciała [Merleau-Ponty 2001]. Negacja tradycji okulocentrycznej umacnia znaczenie ekspresjonizmu. Juhani Pallasmaa twierdzi, że ekspresja artystyczna dotyczy przedwerbalnych znaczeń, które są przez człowieka bezpośrednio przyswajane, a następnie przeżywane, a nie przetwarzane za pośrednictwem intelektu [Pallasmaa 2012]. O takiej też architekturze mówi Dominique Perrault, autor kompleksu budynków Biblioteki Narodowej w Paryżu, określając swoją twórczość jako taką, która trafia do mózgu nie przechodząc przez intelekt [Perrault 2003]. Wpisuje się to w myśl Juhaniego Pallasmaa’y, który zaznacza, że artystyczne zrozumienie bierze się z samej obecności w świecie i obcowania z nim, a doświadczenia te nie powinny podlegać wtórnemu przetworzeniu intelektualnemu [Pallasmaa 2012]. Architektura w „fazie antyracjonalistycznej” jest reprezentowana także przez Stevena Holla, który uważa że funkcjonalne kwestie architektury są „fizyką”, która wymaga opozycji w postaci „metafizyki” [Holl 2013]. Charakterystyczne wielkomiejskie przestrzenie publiczne projektowane przez Holla z założenia, nie wpisują się jednak w architekturę fenomenu tak sprawnie, jak bardziej kameralne realizacje Petera Zumthora Te bowiem zdają się, przynajmniej w sferze ideowej, najsilniej koncentrować na ,genius loci” i tym samym sprawnie operować ekspresją - doznaniem przestrzeni.

Transcendentalna twórczość, odwołująca się do metafizyki oraz fenomenów, zdaje się wykazywać pewnego rodzaju przewagę w stosunku do relatywizmu kosmopolitycznej architektury. Problem polega jednak na tym, że o ile konceptualnie odwołuje się ona do ugruntowanych kulturowo wartości, to sama jej forma nie może wzbić się ponad modernistyczną konwencję formy.

\section{PODSUMOWANIE}

Problematyka relatywizmu w architekturze naturalnie odwołuje się do konfrontacji poglądów postępowych z tradycyjnymi. Obrońcy ujęcia konserwatywnego zakładają, że upodobania dla architektury są stałe i nie ulegają zmianom pod wpływem zewnętrznych warunków, natomiast nowatorzy postrzegają je jako relatywne i zmienne [Sławińska 1997]. Należy więc przyjąć, że podział na wpływy absolutystyczne i relatywistyczne $\mathrm{w}$ architekturze nie jest dychotomiczny.

Rozważania nad współczesnymi tendencjami skłania też do stwierdzenia, że sam relatywizm $\mathrm{w}$ architekturze nie jest zjawiskiem komplementarnym. Zaprojektowana forma zawsze ostatecznie choćby w swej najmniejszej części opiera się na fenomenie pojedynczego kształtu. Tym samym w ostatecznym odniesieniu, relatywizm estetyczny spotka się z koniecznością sprecyzowania „formy pierwszej”, a więc takiej, która nie uzyskała wartości poprzez zestawienie jej z inną. W rezultacie próba podważenia znaczenia ekspresji fenomenu w procesie kreowania formy plastycznej i architektonicznej wydaje się być skazana na niepowodzenie. Przedstawiona prolegomena do tendencji absolutystycznych pozwala z kolei stwierdzić, że absolutyzm przekładający się na formę nie ponosi wyłącznej odpowiedzialności za monumentalizm i nie musi mieć wydźwięku historycznego. Rozstrzygające w przedmiotowej kwestii 
może okazać się stanowisko Stefana Müllera, który twierdzi, że „antagonistyczny dualizm w architekturze współczesnej, z jednej strony szukający oparcia w tworzeniu prywatnego języka, jednostkowego stylu, który będzie tym lepszy, im wyraźniej będzie się odcinać od pozostałych i poprzedzających dzieł, z drugiej zaś - szukający oparcia w racjonalistycznych i technologicznych przesłankach, może i powinien znaleźć rozwiązanie w twórczym sięgnięciu do tradycji, będącej zawsze aktem wiary w istnienie natury ludzkiej i przeciwstawieniem się czystemu historycyzmowi” [Müller 2010]. Wydaje się więc, że kreowanie w architekturze rozwiązań alternatywnych wobec dominującego relatywizmu należy w większym stopniu skoncentrować na fenomenologicznej próbie dotarcia do istoty natury, a w mniejszym stopniu opierać na konfrontacji tradycji z nowoczesnością. W tym względzie ekspresja zdaje się być ważnym elementem określającym nowoczesną kompozycję architektoniczną.

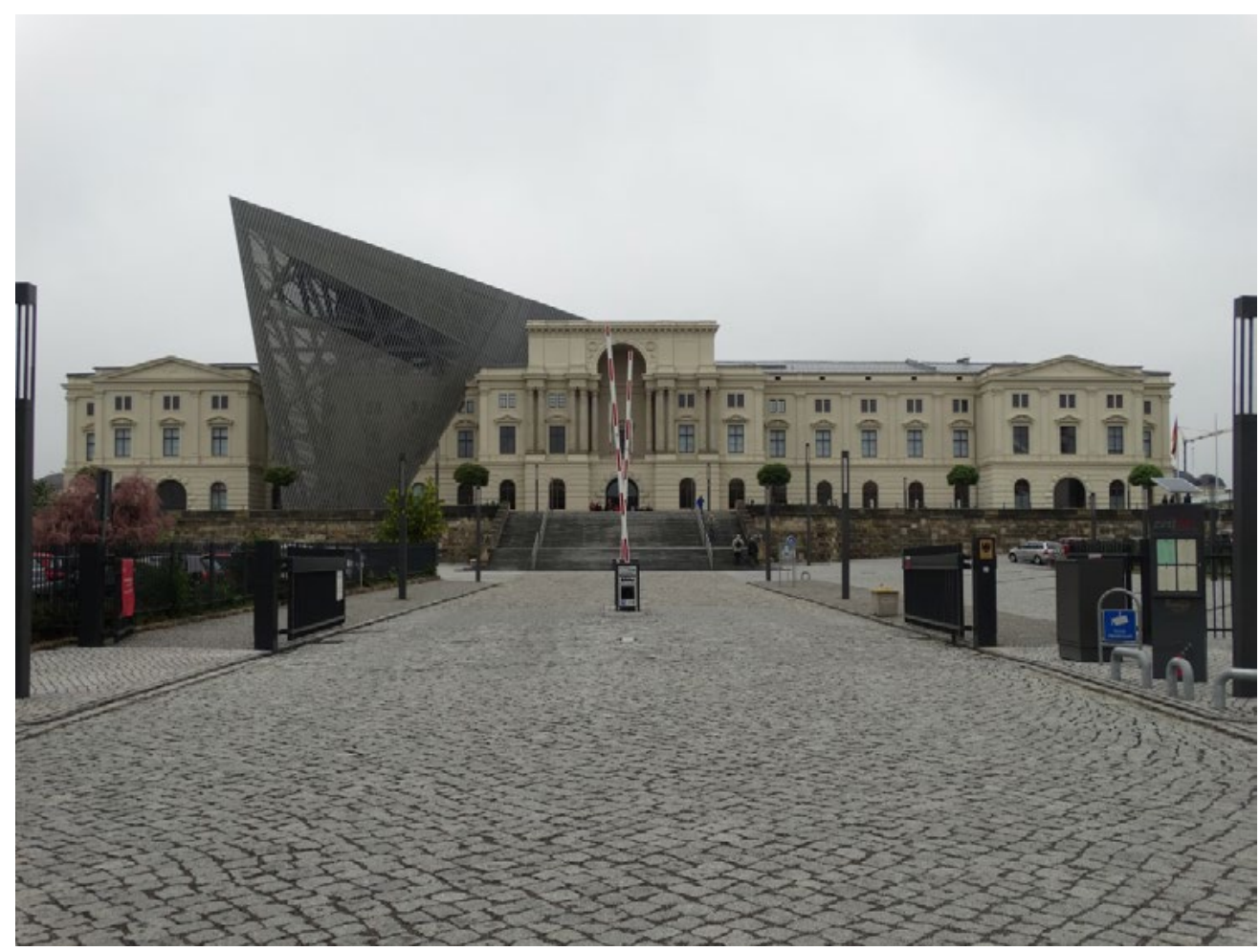

Ryc. 1. Daniel Libeskind, Muzeum Bundeswehry, Drezno, Niemcy - Źródło: Aleksander Serafin Fig. 1. Daniel Libeskind, Bundeswehr Museum, Dresden, Germany - Source: Aleksander Serafin 


\title{
PIŚMIENNICTWO
}

Boccioni U., 1988. Malarstwo i rzézba futuryzmu (in English), Futuryzm, Wydawnictwa Artystyczne i Filmowe, Warszawa, s. 312-321.

Breton A., 1976. Manifest surrealizmu (in French), Surrealizm. Teoria i praktyka literacka. Antologia, Czytelnik, Warszawa, s. 55-102.

Esikot I. F., 2012. Globalization versus relativism: the imperative of a universal ethics, Journal of Politics and Law, 5 (4), s. 129-135.

Harries K., 2000. The ethical function of architecture, MIT Press Cambridge.

Holl S., 2013. Zakotwiczenie (in English), Teorie i manifesty architektury współczesnej, Grupa Sztuka Architektury, Warszawa, s. 132-134.

Kotula A., Krakowski P., 1973. Sztuka abstrakcyjna, Wydawnictwa Artystyczne i Filmowe Warszawa.

Leach N., 1997: Poststructuralism, Rethinking architecture, A reader in cultural theory, Routledge, London - New York, s. 266-368.

Libeskind D., 2008. Przełom. Przygody w życiu i architekturze (in English), Wydawnictwa Naukowo Techniczne Warszawa.

Merleau-Ponty M., 2001. Fenomenologia percepcji (in French), Aletheia, Warszawa.

Müller S. J., 2010. Wynurzenia, czyli nic, Muzeum Architektury we Wrocławiu, Wrocław.

Pallasmaa J., 2012. Oczy skóry (in English), Instytut Architektury, Kraków.

Pawłowski T., 2006. Relatywizm i uniwersalizm, Tadeusz Pawłowski: wybór pism estetycznych, Universitas, Kraków, s. 169-197.

Perrault D. 2003. Na nowy wiek, Architektura-murator. 4, s. 22-31.

Prix W. D., 2005. Baroque Himmelb(l)au. Wolf D. Prix in conversation with René Erven and Bärbel van Zanten | (in German), Get off of my cloud: Wolf D. Prix Coop Himmelb(1)au texts 19682005, Hatje Cantz, Stuttgart, Germany, s. 326-329.

Serafin A., 2013. Abstrakcyjna kompozycja przestrzenna wobec autonomii formy architektonicznej, Definiowanie przestrzeni architektonicznej. Zapis przestrzeni architektonicznej, Wydawnictwo Politechniki Krakowskiej, Kraków, s. 499-504.

Sławińska J., 1997. Ekspresja sił w nowoczesnej architekturze, Arkady, Warszawa.

Sobeski M., 2010. Estetyka obiektywna, Michał Sobeski: wybór pism estetycznych, Universitas, Kraków, s. 30-47.

Tatarkiewicz W., 1970. Historia filozofii. Tom III: Filozofia XIX wieku i współczesna, PWN, Warszawa.

Wąs C., 2010. W stronę dekonstrukcji w architekturze, Quart., 3(17), s. 3-17.

Wigley M., 2013. Architektura dekonstrukcji (in English), Teorie i manifesty architektury współczesnej, Grupa Sztuka Architektury, Warszawa, s. 327-328.

Willett J., 1976. Ekspresjonizm (in English), Wydawnictwa Artystyczne i Filmowe, Warszawa.

Zaguła A., 2013. Arystotelesowskie i religijne źródła Nowego Klasycyzmu w architekturze współczesnej, Wydawnictwo Politechniki Łódzkiej, Łódź.

\section{ISSUES OF RELATIVISM IN THE GLOBAL ARCHITECTURE}

\begin{abstract}
This paper discusses the issues of relativism towards the international architecture but it also confronts them with the opposing ideas. Some examples prove that this sort of architecture as the result of globalism is against the tradition. Despite the presentation of the main aspects of relativism, this article contains the preface to absolutism tendency in architecture. Paradoxically the absolutism of a form does not always mean the neo historical and monumental style. However the relativism is non homogenous style and it has no clear logical limits. Moreover the negation of the traditional values during the design process seems to be doomed to fail.
\end{abstract}

Key words: architecture, relativism, absolutism, globalism, expression, form 